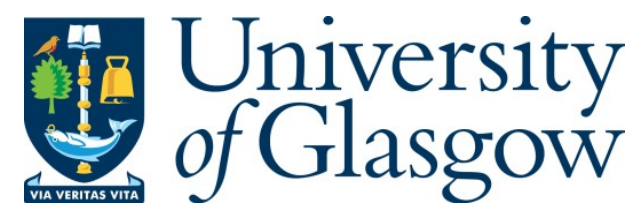

Armstrong, Sarah (2014) Siting prisons, sighting communities: geographies of objection in a planning process. Environment and Planning A, 46 (3). pp. 550-565. ISSN 0308-518X

Copyright (c) 2013 Pion and its Licensors

http://eprints.gla.ac.uk/78218/

Deposited on: 21 May 2014

Enlighten - Research publications by members of the University of Glasgow http://eprints.gla.ac.uk 


\section{Siting Prisons, Sighting Communities: Geographies of Objection in a Planning Process}

Abstract: This article reviews the planning process for a Scottish prison located near a former mining village. Analysing the letters of objection submitted by residents offers an opportunity to explore local views about prison and community and to relate these to the unique social and spatial history of the area. The planning process itself structured how residents were able to express themselves and defined what counted as a relevant objection. After deconstructing this process, the article then restores and uses as a framework for analysis three geographies of objection stripped from local responses to the development proposal: the emotional, temporal and spatial. Emotional expressions of objection added intensity and gave meaning to claims about the historical decline of the region and also conveyed a deep sense of the proposed building site as a lived space. Particular grounds of opposition - over fear of strangers, the fragility of a local orchid, and the pollution from mining - provide an opportunity to explore the complex nature of place meaning and community identity, ultimately leading to a conclusion that the meaning of place is always in flux. The paper srgues that Simmel's classic concept of the Stranger, as the outsider who comes to stay, offers a useful analytic in understanding how the quality of proximal remoteness that prisons and other unwanted developments constitute participate in a constantly evolving sense of the local.

Key words: prison siting, planning disputes, material considerations, objection discourses

Sole, corresponding author:

Dr Sarah Armstrong

Senior Research Fellow

Ivy Lodge

Scottish Centre for Crime and Justice Research

University of Glasgow

63 Gibson Street

Glasgow G12 8LR

+44 (0)141 3308257 telephone (+0 647639 0904, until July 2013)

sarah.armstrong@glasgow.ac.uk

PAGES (including figures and references): 33

WORD COUNT: 8,635 


\section{Siting Prisons, Sighting Communities: Geographies of Objection in a Planning Process}

\section{A Stranger Moves In}

Scotland's newest private prison opened in 2008 and lies about half an hour's drive southwest of the capital, Edinburgh. HMP Addiewell sits on the ruins of a shale oil refinery, one form of industry on top of another. In this article, I revisit the planning process preceding the construction of Addiewell prison, using this as an opportunity to explore local views about prison and community and to relate these to the particular social and spatial history of the area. The application to site a prison in Addiewell village proposed a new feature to a landscape defined by its industrial past and a new neighbour to a community with a history of ambivalence about its heritage. The prospect of this new neighbour opened up a vent for underlying tensions over the meaning of place to erupt and evolve. This article analyses the resulting clash shedding light on the struggle of one place to make sense of its past in the struggle to define its future.

In one sense, this story is fundamentally a local one: arguments for and against building a prison reflected a deeply parochial conflict in which property values and local employment were dominant themes. Yet the story also offers a route into the global. Prisons are one example of the service sector industries that have come to replace industrial and agricultural uses of land (Martin and Mitchelson, 2009; Gilmore, 2007; Hooks, Mosher, et al., 2004; Che, 2005; Davis, 2003; Bonds, 2006) and this story presents a place-based account of how such large scale transformations are felt, 
negotiated and resisted in particular places at particular times (Woods, 2007). At the same time, the local is not merely and instrumentally a tangible illustration of wider global forces, but also an intrinsically important site unto itself, where the forces of globalisation trigger, but do not dictate, reflections on how place matters and changes over time.

How might we reconcile the disparities of scale and perspective in stories involving entanglements of global and local, prisons and communities? There is a temptation to foreground one or another of these elements, or equate them in particular ways: prison as global force, community as local sociality. The strategy adopted here is to focus on the relational status of the sides involved, making use of Georg Simmel's sociological concept of the stranger (1964[1908]). In Simmel's hands, the stranger is a precise analytical concept. The stranger refers not simply to a newcomer but to the new social situation created by "the person who comes today and stays tomorrow [...] He is fixed within a particular spatial group. [...] But his position in this group is determined, essentially, by the fact that he has not belonged to it from the beginning, that he imports qualities into it, which do not and cannot stem from the group itself” (p. 402). It is in the outsider's staying, and the creation and maintenance of spatial proximity, that a relation of social remoteness becomes possible. Hence the stranger concept posits an active relation between insider and outsider, "a specific form of interaction” (p. 402), which is the felt experience of distance. Significantly, the concept marks a social situation arising from a spatial relation (Frisby, 2001).

Analyses of prison siting can tend to treat prisons assymetrically as unexamined Other in comparison to detailed consideration of the communities to which they are imported 
(Davis, 2003; Che, 2005). This in turn presupposes something about the coherence of local communities that excludes prisons from their logic, opposing the two entities in binary terms. The analytic of the stranger does not pre-judge the qualities or impact of any participant in a given setting, but focuses us instead on the relationship dynamics of a group occupying a space and one who comes to settle in it. This relational concept is of particular assistance in analysing the views of residents, the focus of this article, in which pinpointing a specific meaning of the prison gave way to simmering concerns about an emergent sense of place and identity. The aim here is to engage and advance research on prison and place, moving it on from a stance which treats the former unreflexively as an intruder and the latter as separate, prior and complete towards a perspective in which place is always an unfinished space in which incomers like prisons (or wind farms or Walmarts) are not independent variables which impact on things, but are unavoidably enmeshed in a constantly becoming and relational meaning of the local (Clifford, 2000; Ingold, 2008).

\section{Documents as Data and Field}

I explore these themes through analysis of a variety of documents produced during the planning process, in particular the letters local residents submitted during the period of public comment, from December 2003 to January 2004. Although the timing of this project put a practical constraint on choice of method, the primary method of documentary analysis employed in this study is fundamental to its rationale and aims. Like all planning processes, this one structured opportunities for public participation, and the structuring of public involvement is itself part of the query: what kind of community 
is visible through the lens of a planning process? It is through the written record that local views were officially visible to decision makers. That is, the written constituted the form of expression which local government had to take notice of, and for which they could be held accountable in challenges to their decision making, thus forming an important site of contestation and validation. While the social dynamics of a planning meeting, or the reflections of a resident in an interview, would be useful data for the researcher aiming to depict holistically a planning case study, neither of these 'count' as factors which decision makers were required to take into consideration in deciding the planning application.

Documentary analysis as employed here thus is as much a claim about the site of social activity as it is about data availability or method. A review of documents reconstructs and allows us to re-visit the planning process through its official, actionable, traces - in letters, meeting minutes and planning submissions - allowing for the isolation of a significant and contemporaneous discursive space. For example, the environmental statement submitted in support of the prison application was hundreds of pages long, written in in a neutral voice and contained many annexes of maps and tables. Such a statement sets out a particular version of rationality contrasting with that to be found in letters written by private individuals, and consideration of this clash of texts is important for the forensic analysis of their respective logics: "Policy language...is itself a form and source of policy power" to be analysed as a specific genre of style, appearance and use of key words (Apthorpe, 1997: 54; and see Flyvberg, 1998). This resonates with an understanding of policies and their supporting documents as 'inherently and unequivocally anthropological phenomena' requiring analysis as 'cultural texts' (Shore 
and Wright, 1997: 7; Good, 2006). My analysis of texts is guided by an interest in how "policies construct their subjects as objects of power [...]" (Shore and Wright, 1997: 3).

At the same time, by adopting an open-ended discourse analysis of letters submitted by local residents, it is possible to glimpse even in the circumscribed format of their content, a community that was rendered largely invisible through the planning process, one that in communicating anxieties and speculations about the kind of neighbour a prison will be, reveals ambivalence about the community's sense of itself and its place. Hence, an analysis of these texts exposes a more contested space than emerges in work that emphasises outcomes of planning processes or which treats analysis of documents as preliminary to rather than the core of fieldwork. Where interviews and observation allow informants to make sense of themselves to a researcher, my interest is in how local residents made sense of themsleves to an official process and how that process made sense of them, and what possiblities existed within this constrained environment for alternative narratives to emerge. Hence, documents are a site for ethnographic inquiry (Reed, 2006) and their analysis constitutes a form of historical ethnography (Vaughan, 2004).

It is through treating letters of objections as a key discursive space that multiple geographies of objection become visible. The argument of the paper is that, while these dimensions were stripped away by the planning process, restoring them is crucial to 'seeing' this community and its own understanding of place. I group these geographies of objection into three layers: the emotional, temporal and spatial. These overlapping and mutually constitutive contexts offer a broad framework for considering community concerns about the proposal to build a prison in the area. For example, objectors who 
expressed fear and anger about the prison plan had these translated through the official planning framework into specific, tangible (and so addressable) complaints - about the safety of children, the environmental damage of past development, the loss of walking paths. I argue that this affective dimension constituted an important element of an objection discourse in which the prison was temporally connected to a long-term pattern of neglect of the area and, was spatially connected to a lived experience of a semi-rural countryside. After setting out the background to the Addiewell area and the prison planning process, I explore how these contexts give shape and weight to local concern and through the concluding discussion suggest how these might anticipate the evolving meaning of the prison to this community, and the meaning of community to the prison. Throughout, the concept of the Stranger keeps our attention trained on the interaction of prison and place as moving parts rather than fixed entities.

\section{Brownfield of Dreams}

Oil shale mining took place in Scotland from the mid nineteenth century until the discovery of crude oil (petroleum) pushed the industry in Scotland into decline by the 1930s though the last ones closed in the 1960s. The most visible legacy of the mines are shale bings, waste piles left behind by the excavation process and analogous to the slag heaps of the coal industry. The unnaturally perfect pyramids formed by the bings rise up in an area of Scotland otherwise known for being flat and populate a swath of land running through the country's central region from southwest to northeast. The bings are an ambivalent marker of heritage. They memorialize Scotland's brief status as the world leading producer of oil, a source of national pride: the Addiewell works had its "corner stone [...] laid in 1865 by [...] Dr Livingstone (the noted African explorer)” (Redwood, 
1897: 11). They mark the industry's reshaping of the physical and social landscape, leaving behind scenic, but also toxic, hills. A former resident from the mining days remembers the refinery (Figure 1): “An oilwork cannae be nothing else but a dirty smelly place, that's about it. [When] Addiewell was in full process, there was 15 different chimney stacks belching smoke [...] I could mention quite a few whose chests were ruined working on the retorts” (Randall, 1990: 18, 19).

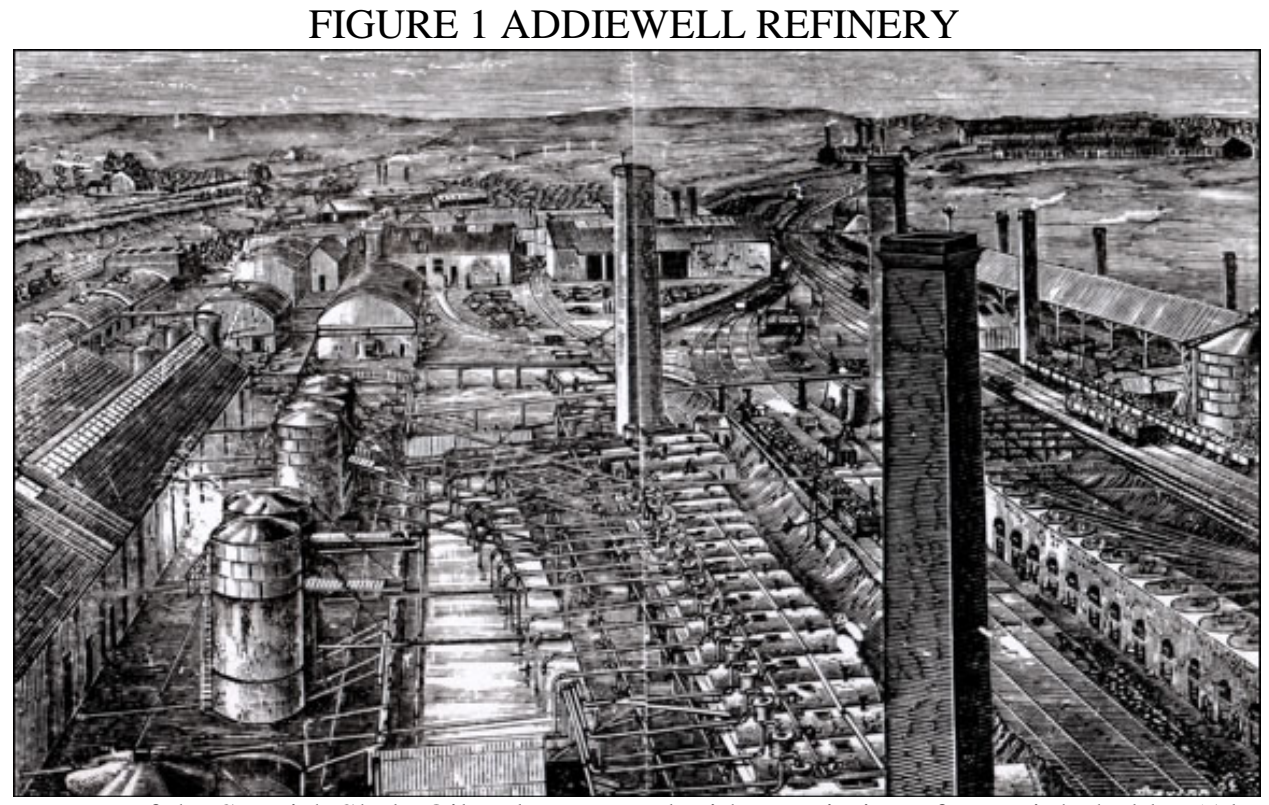

Source: Museum of the Scottish Shale Oil Industry; used with permission of copyright holder (Almond Valley Heritage Trust).

Shale bings are found in the UK only in this part of Scotland with many concentrated around West Lothian, the county in which Addiewell village sits (Harvie, 2005). A linked set of bings called the Five Sisters is so associated with the area that it has been incorporated into West Lothian Council's logo. The rust coloured bings harbour their own mix of plant and animal life with the Addiewell bings alone home to 28 unique plant species, among which are several registered as Nationally Scarce in Great Britain 
(Harvie, 2005: 12-13). Addiewell’s bings are now part of a designated nature reserve, “a good example of how a former industrial site can be transformed into a haven for wildlife” (Scottish Wildlife Trust, 2012). In sum, the bings are not just waste piles made less unsightly through their gradual carpeting by plant life, but a hybrid landscape, part manufactured and part 'natural' supporting a unique and diverse range of life (Figure 2).

FIGURE 2 SHALE BINGS VISIBLE FROM ADDIEWELL

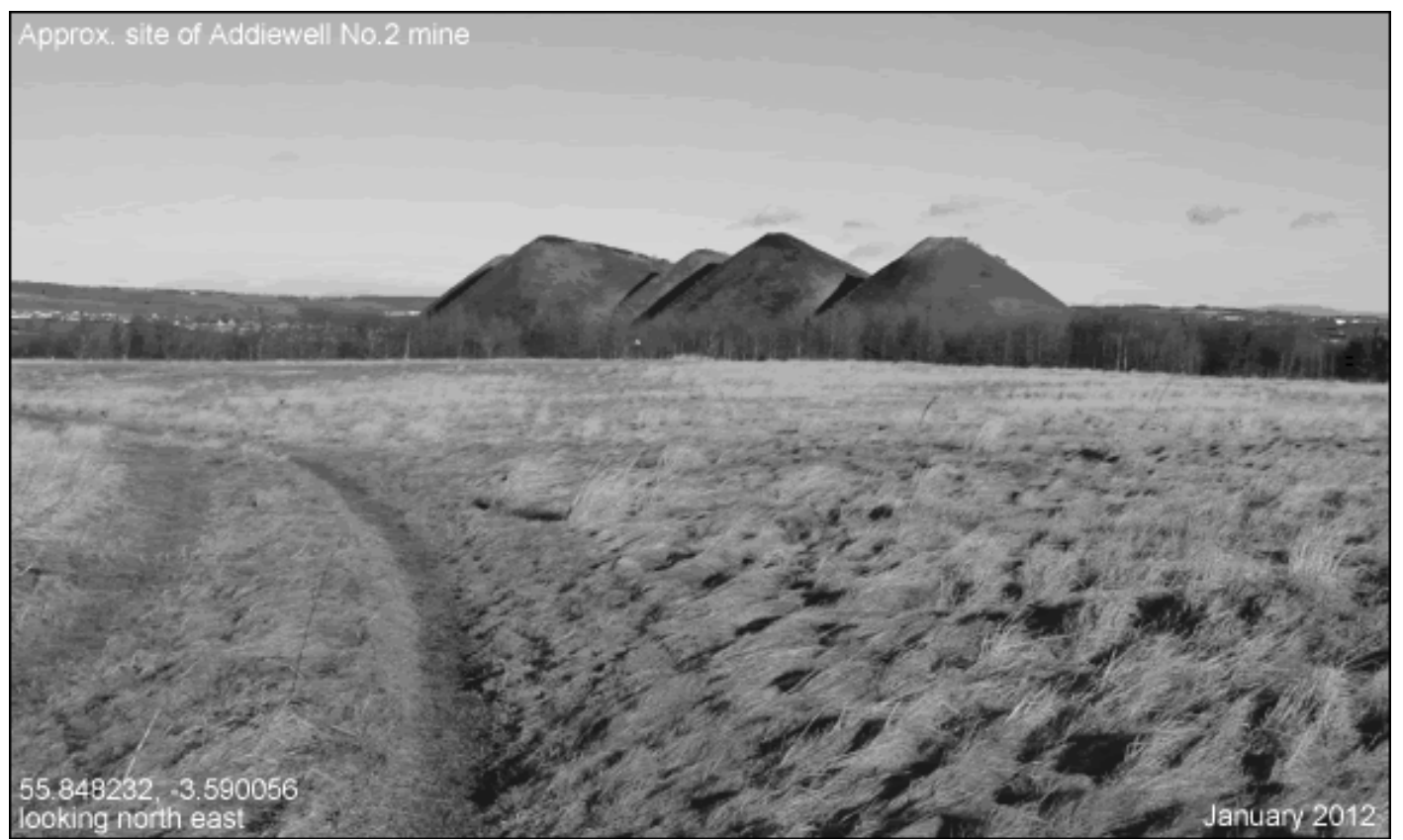

Source: Museum of the Scottish Shale Oil Industry; used with permission of copyright holder (Almond Valley Heritage Trust).

In 2003, the Scottish Prison Service (SPS) identified the brownfield adjacent to the Addiewell bings as its preferred site to build a new prison (Montagu Evans, 2003). The environmental degradation and economic decline of the region, fifty years on from the era of shale oil mining, both counted as points on the plus side of the tally sheet of the site assessment. A new prison would help the area achieve local planning goals by contributing to "a wide range of employment types in West Lothian [able] to secure a sound, robust local economy" and, moreover, "the proposed development is the reuse of a 
former industrial site, and as such, accords with the provisions of national and strategic planning policy" fulfilling the requirement "to improve the environmental quality of the surrounding site” (Montagu Evans, 2003: 27, 29, 28).

Though locals were quick to see a direct lineage between their area's historical role as a mining village and its future one as a prison town, the path of development was more circuitous. In the late 1990s Scotland went hard after the high tech industry, with West Lothian county in particular branding itself ‘Silicon Glen’ after Motorola, NEC and IBM located factories there, and a 1998 area strategic plan set out aspirations to support "a modern high performance knowledge based economy, with world-wide links, creating jobs and a rising quality of life for the people of West Lothian” (West Lothian Council, 2002: 9). The global contraction of the dotcom bubble in 2000-01 (and subsequent loss of over 4,000 jobs locally) shifted the county's focus from private foreign investment as a source of employment towards a strategy of promoting "West Lothian as a location for public sector agencies” (West Lothian Council, 2002: 17), the partial realisation of which included re-opening a recently shuttered NEC factory as an Inland Revenue tax processing centre (BBC, 2003).

It was in the shadow of these changes that in late December 2003, the SPS formally submitted its proposal to buy the Council owned brownfield site abutting Addiewell and West Calder villages to build and operate a 700-bed prison. A total of 80 letters (71 from residents of the two villages, two from their community councils, and the remainder from national organisations with mainly neutral views, like the Health and Safety Executive) were received in response to the call for public comment from mid December through about 30 January 2004 (Hartland, 2004). Despite the objection letters, a petition bearing 
1,350 signatures, a claim from West Calder's community council that $80 \%$ of residents opposed the prison plan (Hartland, 2004), several rowdy public hearings, and national newspaper coverage publicizing local opposition (The Scotsman, 2003, 2004a and 2004b), outline planning permission was approved in mid-2004. An appeal to Scotland's national legislature was rejected, and final approval for the prison plan was given in July 2004. As a Government spokesman explained: "Ministers would only consider intervening in West Lothian's decision where the application raises issues of national significance....In this case, ministers were satisfied that the application did not raise planning policy issues sufficient to warrant their intervention” (The Scotsman, 2004c). A spokesman for a local anti-prison group said of the decision, "This is bewildering. I think that the powers that be are walking all over the feelings and objections of the local community.” (Id.). In 2006 a consortium of the construction company Interserve, the private prisons operator Sodexho (formerly Kalyx, formerly UKDS) and the Royal Bank of Scotland won the contract to finance, build and operate HMP Addiewell. The prison opened for business in December 2008, reaching its maximum capacity of 700 prisoners a few months after.

\section{Communities, Prisons and Planners}

If formal planning processes are important discursive sites worthy of examination, the major challenge in excavating such sites is that they are set up to limit access of those participating in them. Public hearings may appear to provide opportunities for direct public participation while effecting such rigid control over the terms of participation that actual influence is nearly eliminated (Topal, 2009). In this way they can function as a legitimating practice that simultaneously enacts and deepens institutional power (Topal, 
2009). Research specifically on letters of objection found that they have had very limited influence, possibly delaying but not altering outcomes (Aitken et al., 2008). One critique found across the literature is that rather than "a more broadly participatory approach to planning” reforms to legislation have mainly "created opportunities for groups that are already powerful either financially or in terms of expertise and influence" (Smith 2004: 36, and see Flyvberg, 1998).

Such controlled opportunities of public input not only limit the amount of data for analysis, but have essentialised public opposition to developments like prisons as simple NIMBYism, justifying the limits on public participation in planning (Ellis, 2004). But claims of NIMBYism are not only a feature of prison planning debates but also a tactic, an accusation that atomises local concern into un-neighbourly self-interest, reducing residential communities into individuals whose concerns over property prices and safety can be dismissed as alarmist and lacking in evidence. Even if objectors are broadly motivated by self-interest, however, they also "may be articulating genuine and rational concerns over quality-of-life issues that they can reasonably expect the planning system to take into account.” (Ellis, 2004: 1554, citing Barry, 2003). Moreover, a focus on NIMBYism obscures the social, cultural and economic context of development (Gilmore, 2007; Freudenberg and Pastor, 1992; Lake, 1993). Consideration of the wider context is crucial in the case of prison siting because of the rapid expansion of prison construction in the 1980s and 1990s and the investigation of this as a forced migration and containment of society's least desirable members (Davis, 2003; Hooks, Mosher, et al. 2004; Wacquant, 2001). 
Ellis (2004) reaches past essentialism of local opposition to identify multiple 'discourses of objection' in his case study set in Ireland. He found a variety of sometimes conflicting motivations and beliefs driving views about planning. Revealing the different strands of objection requires attention to "the interaction between the structural forces in society and the fine-grain practices and discourses of governance” (Ellis, 2004: 1563). Short of this, consideration of planning processes can tend to become functionalist, focused on whether or not local opposition 'succeeded' in derailing a development proposal. The letters of objection submitted in response to the Addiewell prison proposal provide just the kind of fine-grain detail which can illuminate and facilitate connections to the wider context of the area's history and the global issue of prison expansion. Before analysing these, we need to account for the filter set up to control how these letters were interpreted by the official process: the 'material considerations' framework that governs the UK planning system.

\section{The Material Considerations Framework}

In order to have one's views taken into account, and thus to be visible, in a planning process one must say something that is relevant. In Scotland, for "a consideration [to be] material and relevant it should serve or be related to the purpose of planning. This means it should relate to the development and use of land” (Planning Aid Scotland, 2012). Examples include such things as the proposed development limiting the natural light to property, detracting from the general amenity of the local area or having an adverse effect on the environment (Ibid.). The material considerations framework is familiar to anyone who has come into contact with a planning process in the UK, but rarely does it come 
under scrutiny as a social construction that institutionalises historically and politically contingent ideas about what matters.

Success in avoiding scrutinty may flow partly from the effect of its self-evident rationality, which aims, quite sensibly, to screen out unreasonable, tangential and unspecific complaints about development. The Addiewell prison objections feature countless examples that fail this test of materiality. Letter writers complained that: councillors backing the plan will not have to look at the prison everyday from their kitchen windows; famous people who have come from the area would be aghast at development plans; adding another prison to central Scotland would create a "triangle of despair". All these comments stray from the specifics of the design and impact of the prison as proposed. And none of these concerns fall within the "[n]ational and other planning policies identified as material considerations” by West Lothian Council's planners which included such considerations as the impact of planning on architecture, urban drainage, transport, archaeology and natural heritage (Hartland, 2004: 2-3).

What appears as self-evidently rational, however, may be supplying cover for a rationalization, a process by which the interests of some are prioritised over others through justifications which appear neutral and efficient. Rationalization typically presents itself as rationality according to Flyvbjerg (1998), as "a principal strategy in the exercise of power....The 'untouchable' position of rationalizations may be due to the fact that [they] are often difficult to identify and penetrate: they are presented as rationality" (1998: 228-229). Hence, by setting out only one possible construction of relevance, other constructions are rendered irrelevant and thus irrational. If we were to ignore the material 
considerations framework, however, it is possible to construe relevance out of these local objections in that they cumulatively build up a sense of Addiewell as a place: with a heritage worth protecting (vide the famous people it has raised); that exists in hierarchical relation to other places (the distant county seats where officials make policy); and which participates in a larger national narrative (the tragedy of Scotland's high imprisonment rate). Denial of this place context allows Addiewell to be treated abstractly as a generic space to be arranged at a distance by Council planners, with siting of a prison justified as serving the greater good, in this case the county (to realise an area economic strategy of public sector jobs growth) and the nation (to meet demand for prison spaces across Scotland). Such a rationalised logic reflects an "economistic mode [of government] that takes land as mere abstract space for the maximisation of economic and administrative interests with little regard for cultural or social concerns” (Ku, 2012: 7).

There are many examples in the Addiewell prison process where the material considerations framework not only filtered out important elements of objections but also channelled what remained into forms of expression that tended to encourage narrow interpretations of community opposition. This work was assisted by the objectors themselves. Seeking to maximise the chances that residents' views would be heard, an opposition group formed of local residents leafleted the communities of Addiewell and West Calder to explain the need of putting concerns into the language and format of the material considerations framework, providing a letter template with examples of objections that would count. The vast majority of letters subsequently adopted a similar formatting and vocabulary. 
Despite this, letter writers who followed the template (and the few who ignored it altogether) all display idiosyncratic touches which suggest more than a self-serving obstructionism is at work. A more reflexive notion of relevance, however, found no space in a planning process that extracted only officially recognisable concerns about traffic, visual appearance, crime and so on. The splitting of local concern into technical planning issues eased the ability of the Council either to reject or to appear to be addressing opposition. This was exemplified in concerns many objectors expressed about a prison’s impact on the nature and use of the space around them:

“The proposed site is widely used as an amenity area by the local people. There is a large area of open ground which is ideally suited for parents to take their children where they can enjoy themselves in complete freedom and safety...There are orchids all over the site with very large concentrations in some areas.” (Letter 2)

These views were aggregated and translated for councillors in the official planning report as:

"The [residents feel] development of the site will result in the loss of a natural habitat which currently supports wildlife and plants, in particular the common spotted orchid.” (Hartland, 2004: para 7.4)

Which produced a specific issue for decision and action:

"in response to the presence on site of the common orchid an operational plan is required which would identify the areas to be relocated, the means of removal and placement, ground preparation and turf establishment, management and monitoring arrangements” (Hartland, 2004: para. 11.9).

A wild and free place to wander became an anonymous space of vegetation, no more special than a gardening centre from which plants are constantly removed and re-homed. 
"There is a danger that emphasis on classifying as a way of describing the vegetation on the bings will result in the loss of awareness of the dynamics of the successional processes by 'putting concrete vegetation into abstract boxes'” (Harvie, 2005: 12, quoting Legg 1992). In this case an amorphous notion of nature was put into concrete boxes. The example of the orchids, addressed further below, shows how overlaying a material considerations framework onto local views allowed for selective identification of issues which were most susceptible to official action. The material considerations framework thus operates as a translation process, first disaggregating and then reconstituting local concern.

\section{Immaterial Considerations}

\section{Emotions of objection}

"I therefore DO NOT agree with any of the proposals you have or are putting forward for this proposed project.” (Letter 15)

This section is set on the cutting room floor. It picks through the bits left out of the Council's consideration, deemed immaterial implicitly through exclusion from the official planning reports. The quote above provides a useful example: it offers no substantive concern about the prison plan. It exemplifies the opening phrasing of the vast majority of letters in which an opening line about 'strongly', 'strenuously', or 'vehemently' objecting to the prison is followed by a bullet point list stating substantive concerns and then signed off with a line in the same spirit as the opening: "In short, [the Council] should most definitely not grant...” (Letter 1, emphasis in original); "Very Dismayed” (Letter 36); “Please count me as an objector!” (Letter 39). The use of 
capitalisation, bold type, exclamation points and particular adverbs are treated as ornamental and dispensable.

Emotions normally have no place in rational decision making forums, and in this instance the decision about the prison application proceeded based on materials and documented discussions that entirely excised the affective. However, revisiting affective responses to the prison plans allows us to evaluate claims that community opposition to prisons tends to be fuelled by, on the one hand, cynical, or, on the other, hysterical concern about property prices and crime. The emotions expressed in the prison objectors' letters included: fear, stress and worry; anger and outrage; humour, irony and surprise; happiness and nostalgia. A few examples show how emotion works to give meaning to objections.

Nostalgia and sadness in the letters often related to a sense of connection to a place and, specifically a rural setting that connected past, present and future generations through a shared way of life. Something important about the way I live is about to change, such feelings seem to be saying:

"My worries include the impact to the wildlife, for example, the swans, the wildflowers, having spent many happy hours with my children in years gone by I am saddened that in future this might not be possible for the neighbour's little boys.” (Letter 50, attached to which is a photograph of two swans and their brood)

Objectors seemed to be articulating worries over something bigger and less tangible than a prison, of something at risk or already in the process of being lost, the kind of life 
possible in a safe and quiet village. Affective expressions, in other words, were one mechanism of communicating holistic and pre-existing concerns about community.

"Livingston, West Calder Addiewell and many of the surrounding areas already have more problems with drugs, rowdy youths etc. than the police can handle. A prison will only encourage more drugs into the area.” (Letter 11)

But just as often, fear and worry were communicated directly in the form of a personal appeal and using the mechanism of formatting. Worries conveyed without reference to a planning consideration found no place in official summaries, and amounted therefore to saying nothing at all. What is lost in the exclusion of these expressions is the intensity of objection.

“'One final question,,,,,,,,,,,,,,,,,,,,,,please ask yourself,,,,,,,would I like a prison to be built on my doorstep? ,,,,,,,,,,,,,,,and feel a fraction of the worry and stress we are being put through.” (Letter 59)

In contrast to a process that grouped objectors by issue, affective expressions allowed quirky individuality to emerge. This is especially visible in use of humour and irony:

"My concern is for the prisoners. West Calder is a degenerate, wipe-your-feetwhen-leaving sort of place and the particular site you have chosen for construction of your prison is one of the least scenic imaginable. These poor chaps will have no outlook whatever. A vista of bings, industrial dereliction and sub-standard public housing will depress them terribly.” (Letter 66)

“The late Fr McMahon always said Addiewell would rise again but I don’t think he had a prison in mind.” (Letter 18) 
The emotions here reveal ambivalence in attitudes about the area, in the indirect references to its history of industrial decline and environmental degradation, and expressions of hope in its rising again. Basic opposition to the prison proposal may partly have been based on unfounded speculation about a prison's impact on local crime and community safety. But we should guard against conflating the importance of emotions with the accuracy of the beliefs underlying them. In this case, the affective expressions allow one to distinguish a variety of views not so much about the prison but about the community in which it might settle. Letter writers fretted about losing a place of happy memories, poked fun that a prison would count as an area improvement, and conveyed the stress that decisions being made far away would have an impact on a local way of life. It is not the worry of losing Shangri-la that is at the heart of affective responses. Rather, emotions conveyed the image of a damaged community and a sense of helplessness before the forces driving change. Fear of the prison in this case cannot be reduced to an ignorant rejection and prejudgment of the unknown, or a desire to protect one's own utopia, but speaks more of an anxiety about losing control over a place in transition when a stranger comes to settle.

The role of emotions in planning and policy processes is gathering increasing research attention (Anderson and Smith, 2002; and generally in social research, Widdowfield, 2000). Conventionally, the emotional dimension of policy debate is viewed as a distraction to rather than component of good decision making. But processes set up to facilitate rational decision making, as is the case here, are "emotionally heightened spaces” which require accounting for, rather than removal from, analytical consideration given that "social relations are lived through emotions" (Anderson and Smith, 2002: 8, 
9). The anger expressed in many letters conveys a sense of injustice at the neglect of their community relative to others: "The council did not even bother to put up Christmas lights in Addiewell!” (Letter 65). The affective layer of objection in letters establishes a mood and tenor but also forms an essential part of a substantive objection to Addiewell's designated role in a larger regeneration strategy. That is, expressions of sentiment were embedded in views about the land as: polluted, cherished, inappropriate for development, essential to a way of life, neglected. Emotions also added intensity to specific concerns, constituting a geography of their own. Though beyond the scope of this paper to explore fully, we can see the planning process rolling over this landscape, flattening spikes of affect and thus levelling distinctions between the range of concerns expressed. This had the effect of preventing both prioritisation of local concerns and a holistic understanding of local opposition.

A community at risk, a community hard won: the temporal context of objection

“A by-pass for West Calder was 'on the cards' some 40 years ago but we seem to be the 'forgotten' village.” (Letter 24)

"We have to watch while other parts of the county have swimming pools, new community centres and sports facilities. I have lived here for 30 years and waited in vain for 20th century improvements to reach here.” (Letter 40)

The meaning of space is always in flux, though there are certain points in time when negotiations over meaning take on particular intensity and significance. The proposed prison plan fomented such a moment. While the prison was targeted as the main threat to valued meanings of place, it became apparent that the prison application also allowed prior tensions over meanings to surface. One of the tensions played out in depictions of, 
on the one hand, a deprived and underserved former mining community, and on the other hand, an idyllic rural setting with a prideworthy industrial heritage. Each depiction entailed specific arguments against a prison being sited in their midst, revealing both aspirations and ambivalence about a place defined by its history.

That both these perspectives were simultaneously possible displays how fragile the meaning of place had become at this point in Addiewell's history. Far from being convinced that a prison would breathe new life into the area by creating jobs and improving the landscaping of a derelict brownfield, local objectors saw the prison as an all too familiar incomer. The prison would be one more instance of the area's use as a dumping ground:

"My own village ... is surrounded by unwelcome "tipping”. We already have Shotts prison on our doorstep, landfill at Headless cross, Levenseat quarry, and Levenseat landfill. and [sic] proposed windfarms on the moor above Levenseat.” (Letter 4)

"The site is a soft option for the SPS to exploit...the likely strength of opposition from battered mining communities... is less than in more upmarket areas of our county.” (Letter 51)

Addiewell had reached its own tipping point: would it become established as a toxic dumping ground or a proud heritage site? The prison was seen by objectors as a decisive push in the direction of the former. In summarising concern, the official report to the Council's planning committee rendered objectors' views as follows:

"[It is argued that the] proposed site is regarded as being inappropriate for a development of this nature, given its semi rural location between two small 
villages and its physical relationship to existing houses. It is feared that it will stigmatise and erode the character of Addiewell in particular and be detrimental to the amenity of neighbouring residents in terms of security, privacy, noise and intrusive lighting.” (Hartland, 2004: para. 7.4)

The planning summary links concerns about the loss of village character to the location of the prison being near residences and constituting a structure that is out of keeping with the area's look. Loss of a way of life becomes in the language of material considerations 'loss of amenity' which can be parsed into a list of gripes about lighting and noise. What the historical context restores to this summary is an understanding that what is at stake is not just a desirable place to commute from, but a sense of community and place that was hard won over time from the mining industry. The triumph over the past is not complete, however, and much of the emotion expressed in letters conveys the sense of fragility of gains made. Comparing the following excerpts shows the the knife edge on which the community teeters between interpretations of this past as proud or shameful and the present as endangered or determined:

"Why is it, when we are trying to develop the rich history of the shale mines, the coal mines and the Paraffin Young Heritage we are going to impact the community with the huge eyesore of a prison building?” (Letter 32)

“Slag heaps [are] our National Monument to corporate greed.” (Letter 5)

Addiewell prison was not involved in the creation of the shale bings, yet was widely perceived among local residents to have the power of changing their meaning. The prison as Simmelian Stranger thus does not directly impinge on the group, but nevertheless may carry influence by prompting reflection upon the nature and history of the connection to 
land. The problem of strangers arose in more explicit, though polysemic, ways in the spatial context of objections, considered next.

Flowers, cars and strangers: the spatial context of objection

One prominent battleground in the Addiewell prison debate formed around a flower, the common spotted orchid. A tactical purpose for objectors to invoke the orchid was that, at the time of the prison application, it was in the process of being named the county flower of West Lothian. Although the orchid was neither the rarest nor most threatened plant on the bings - distinctions belonging to a group of unphotogenic mosses and lichens (Harvie, 2005) - it offered one of the few points of traction for the objectors. The orchids possessed favoured resident status in Addiewell around which other local residents could rally in defence. Among the many references to the orchid in letters is this one:

"I visited the site during the summer when thousands of wild Orchids were in bloom [...] Proliferation on such a scale is unique and my question is - if this was situated in the Bathgate Hills [near the county seat] what would be the Council's response? No doubt there would be much trumpeting of saving the Orchids for the people of the county.” (Letter 40)

Invocation of the orchid entailed a mix of 'strategy and sentiment' typical of debates over heritage sites (Paulsen, 2007). Residents' reflections on the orchid established the landscape's conservation-worthy quality, an unintended but treasured consequence of the mining industry. Making an issue out of a flower was clearly strategic but also connected to reflections on the area's transition from industrial wasteland to wildlife haven. It offered a way of articulating the meaning and significance of a lived natural space within the material considerations framework, by identifying an immediate, tangible (and 
therefore relevant) threat to the environment that would be created by the proposed development.

It is difficult to imagine a sharper contrast to an orchid than a prison, which objectors variously referred to as: a "monstrosity [...] imposed on the doorstep of Addiewell village” (Letter 3), “this massive edifice” (Letter 5), and a "monumental monstrosity lit up at night” (Letter 18). The translation of these complaints into a recognised material consideration - that the prison's size and design was out of keeping with the surrounding area (Hartland, 2004) - fatally diminished the fundamental meaning of the concern that a large, manmade, permanently lit monolith was not just out of keeping with but would irrevocably destructive of a space that could be home to a delicate flower.

The power but also risk of symbols is that they can encompass multiple and conflicting meanings (Stone, 2002). The county planners were able to recognise the plant's privileged status in simply re-locating it to other parts of Addiewell's green space. In this way, the planning process chopped out and treated as wholly autonomous what for locals was an inseparable metonym of their lived experience of nature. The isolation of the object from its place denied one of the central convictions across objection letters, that the meaning of space and the objects within it are mutually reliant and constituted (Ku, 2012).

A second theme emerging from the spatial context concerns conceptions of freedom. Often freedom was interpreted through a construction of the area as a natural, wild place: 
"I have been a resident in this area all my life, growing up in the local village [...] I enjoy walking and having the wild life on my door step...[T]he freedom I once had will be taken away...” (Letter 54)

This was juxtaposed to the constraining qualities of urban spaces:

"People need space to thrive and if it is not given then it is likely that this area will soon suffer the same problems as some parts of Livingston and other ‘concrete jungles'.” (Letter 70)

A construction of nature as a wild, minimally populated place was not the only component of this sense of freedom.

"We ... have two young children who are fortunate to enjoy more freedom than their counterparts [living in cities]. They are able to cycle and go for walks, not only along the 'bing' which is the site proposed for development, but also along our own road and surrounding area, without the fear of too much through traffic, or strangers.” (letter 29)

"[W]e are raising our children in the safety of everyone knowing whose child is playing outside and protecting them if a Stranger approaches or, assisting them when crossing roads [to avoid] speeding cars.” (Letter 26)

Space to roam, space free from cars and space safe from strangers are tied together. It is a construction of freedom articulated partly through the idea of security: securing the physical safety of children (from traffic and human predators) the emotional freedom of parents; and space for wild environments to flourish. Once this meshwork of security and freedom is untangled into a neat list of planning issues about traffic levels, criminal activity and the natural environment, the placeness of this space dissolves into the routine, generic management issues of any locality. 
The presentation of the prison as a threat to security constitutes it as the ultimate outsider. Its presence will destroy a native way of life. The prison monolith contrasts drastically with the preferred spatial symbol of the orchid. Its role as a repository of 'despair' threatens to suffocate the joyful affective experience of the area's residents. It is a container and magnet of 'Strangers' and 'unsavoury characters' and traffic who do not belong to this place. But another interpretation of these letters, embittered though their writers may be about it, is that the prison will fit perfectly into this neighbourhood of dereliction, toxic pollution and other unwanted development.

"The site is well known for being unstable (unsuited to buildings) and has many toxins, from past use of the site, locked away. These toxins will be released during the construction phase and [...] these toxins will get into the water system.” (Letter 2)

The prison is the Other of an imagined future, and at the same time the familiar of a despised past. Arguments about the unsuitability of the land for development as a prison site deploy toxicity literally, but also as a metaphor for the history of an area in which the past is a toxic substance, barely contained. Constructing a prison on the site allows the the industrial exploitation of this past to leak out.

The strangeness of the prison in these concerns aims at equating something which is unwanted as something which therefore does not belong. The binary of certain desirable but precarious freedoms of childhood and nature are set against the undesirable and imprisoning effects of traffic and new people, captured in the symbolism of a flower and a juggernaut. 


\section{Conclusion}

This snapshot of local views marks an intense period of reflection and debate, and thus an inherently unstable moment, from which it is impossible to fix any generalisations about how the local community will come to view the prison that now has been built. But perhaps we can work with this instability, seeing in the application for the Addiewell prison the creation of an opening in which the fluidity of place identity is not just exposed but also developed, building on Clifford's (2000) notion that place is never fixed by any particular meaning. The Addiewell prison planning process created a space for simmering understandings to bubble up and take shape in the form of letters. These concrete articulations in turn become part of a landscape in which Addiewell prison forms part in of a local identity.

The prison as a 'familiar stranger' in Addiewell resonates with Simmel's analytic in that its nearness stabilises a felt experience of difference. That is, the Stranger's lack of assimilation itself is part of a new, stable social form with unique dynamics. Simmel's concept stops us from taking the side of the group towards the incomer - as the one who will never belong - focussing us instead on how the presence of this other participates in the group's evolving sense of its place. Attention to the temporal context of objection reminds us that the meaning of place is always in a state of becoming, with no beginning or end, where even the past can be unsettled by developments in the present.

The spatial context of objection materialises the stranger's effect of distance-in-place. Simmel's concept of the stranger leads us to acknowledge that the group's sense of estrangement is itself a form of identity, and transition is the steady state of place meaning. Ironically, the translation of local concerns into specific, material considerations through the planning process encouraged the prison's designers to take 
account of local concerns at the same time it distorted what those concerns were. The prison's agents offered extensive path development and landscaping to assuage local objections, which literally and symbolically created more distance. Neatly planted trees and paved walkways marked out the prison's boundaries and its own style of environmental impact, a planned aesthetic re-design from the untidy, unintentional and gradual landscaping by the shale bings (Figure 3). The stranger thus embeds itself, inserting new forms and understanding of nature through the shaping of the landscape. The stranger who has come to stay is now making its own impression, no longer just responding to, but now also participating in shaping local meanings of this place.

\section{FIGURE 3 HMP ADDIEWELL ON SITE OF OLD CHEMICAL WORKS}

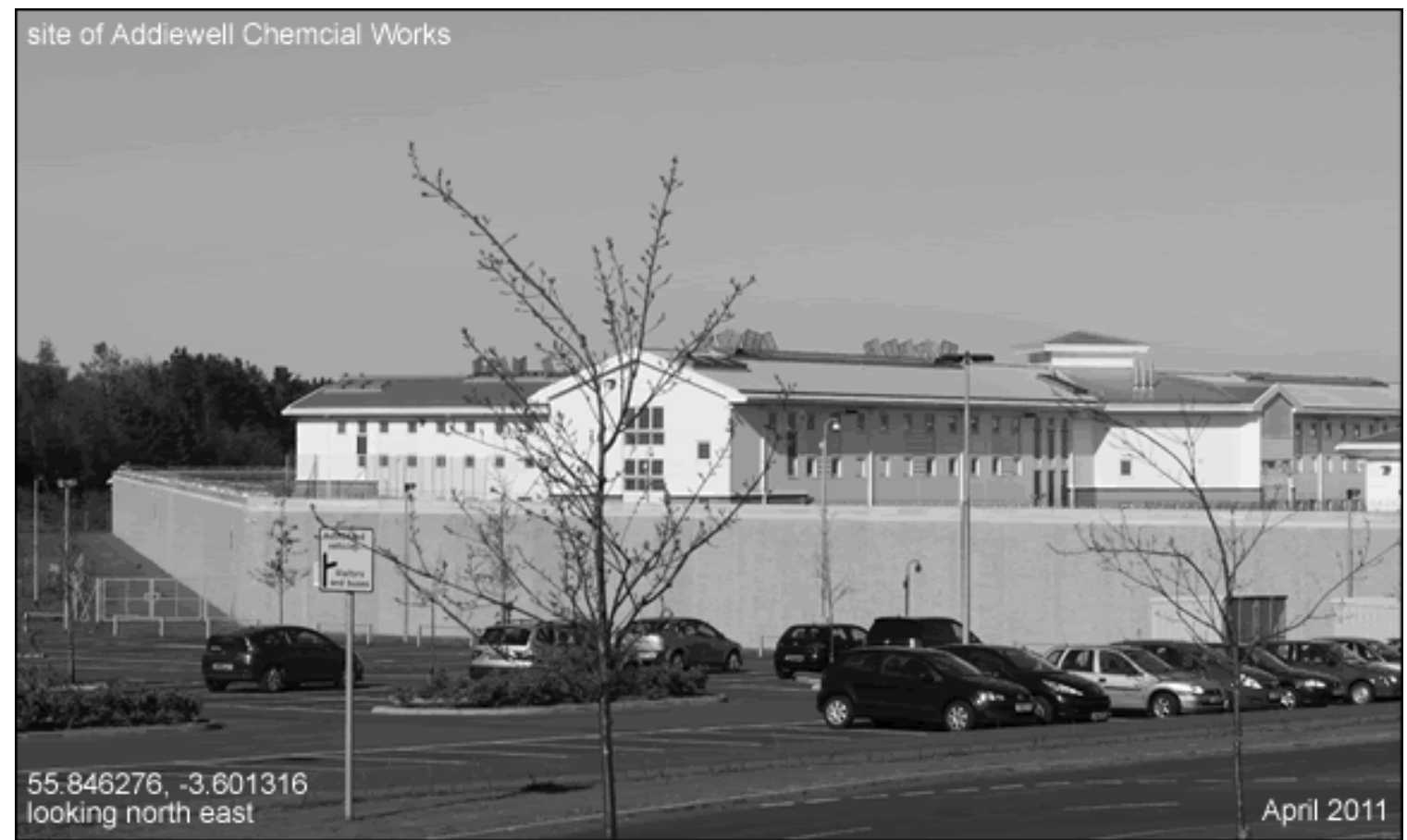

Source: Museum of the Scottish Shale Oil Industry; used with permission of copyright holder (Almond Valley Heritage Trust) 


\section{References}

Aitken M, McDonald S, Strachan P, 2008, “Locating 'power' in wind power planning processes: the (not so) influential role of local objectors” Journal of Environmental Planning and Management 51(6) 777-799

Anderson K, Smith S, 2002, “Editorial: Emotional geographies” Transactions of the Institute of British Geographers NS 26 7-10

Apthorpe, R, 1997, “Writing Development Policy and Policy Analysis Plain or Clear: On Language, Genre and Power” in Anthropology of Policy: Critical Perspectives on Governance and Power Eds C Shore and S Wright (Routledge, London) pp 34-45

BBC, 2003, “Inland Revenue creates jobs boost” 26 November, http://news.bbc.co.uk/1/hi/scotland/3239168.stm

BBC, 2004, "Plans for new prison put on show" 2 January, http://news.bbc.co.uk/go/pr/fr/-/1/hi/scotland/3331765.stm

Berube A, Singer A, Wilson JH, Frey W, 2006, “Finding Exurbia: America’s FastGrowing Communities at the Metropolitan Fringe” The Brookings Institution, Living Cities Census Series, Washington DC

Bonds, A, 2006, "Profit from punishment? The politics of prisons, poverty and neoliberal restructuring in the rural American northwest” Antipode 38(1) 174-177

Burningham K, 2000, "Using the Language of NIMBY: A topic for research, not an activity for researchers” Local Environment 5(1) 55-67

Cadieux KV, (2011) “Competing discourses of nature in exurbia” GeoJournal 76 341363 
Che D, 2005, "Constructing a Prison in the Forest: Conflicts over Nature, Paradise and Identity” Annals of the American Association of Geographers 95(4) 809-31

Clifford J, 2000, Interview with James Clifford by Alex Coles Site-Specificity: The Ethnographic Turn, de-, dis-, ex- Ed A Cole (Black Dog Publishing, London) pp 5273

Davis A, 2003, Are Prisons Obsolete? (Open Media, New York)

Ellis G, 2004, "Discourses of objection: towards an understanding of third-party rights in planning” Environment and Planning A 36 1549-1570

Flyvberg B, 1998, Rationality \& Power: Democracy in Practice (University of Chicago Press, Chicago)

Freudenburg W, Pastor, S, 1992, NIMBYs and LULUs: Stalking the Syndromes” Journal of Social Issues 48(4) 39-61

Frisby, D, 2001, Simmel and Since: Essays on Georg Simmel's Social Theory (Routledge, London)

Galloway K, Kutchins P, 2007 Prison Town USA Documentary PBS/ITVS co-production Gilmore RW, 2007, Golden Gulag: Prisons, Surplus, Crisis, and Opposition in Globalizing California (University of California Press, Berkeley)

Glassmeier A, Farrigan T, 2007 “The Economic Impacts of the Prison Development Boom on Persistently Poor Rural Places” International Regional Science Review 30(3) 274-299

Good, A, 2006, "Writing as a Kind of Anthropology: Alternative Professional Genres” in Critical Journeys: The Making of Anthropologists Eds G. De Neeve and M. Unnithan-Kumar (Ashgate, Aldershot) pp 91-116 
Hartland R, 2004, Report by Development and Building Control Manager for the Development Control Sub-Committee Ref. No.1375/P/2003 \&1376/NPD/2003 (5 May 2004) (West Lothian Council, Livingston)

Hartland R, 2005 Report by Development and Building Control Manager for the Development Control Sub-Committee Ref. No.1086/2005 (7 December) (West Lothian Council, Livingston)

Harvie B, 2005, West Lothian Local Biodiversity Action Plan - Oil Shale Bings, Study commissioned by West Lothian Council, http://www.westlothian.gov.uk/media/downloaddoc/1799514/1842967/oil_shale_bi ngs

Hooks G, Mosher C, Rotolo T, Lobao L, 2004, “The Prison Industry: Carceral Expansion and Employment in U.S. Counties 1969-1994” Social Science Quarterly 85(1) 3757

Ingold, T, 2008, “Bindings against boundaries: entanglements of life in an open world” Environment and Planning A 40 1796-1810

Ku, AS, 2012, "Remaking places and fashioning an opposition discourse: struggle over the Star Ferry pier and the Queen's pier in Hong Kong” Environment and Planning D: Society and Space, 30 5-22

Lake R, 1993, “Planners' Alchemy Transforming NIMBY to YIMBY: Rethinking NIMBY” Journal of the American Planning Association 59 87-93

Martinson L, Mitchelson M, 2009, “Geographies of Detention and Imprisonment: Interrogating Spatial Practices of Confinement, Discipline, Law, and State Power” Geography Compass 3(1) 459-477 
Montagu Evans, 2003, Supporting Planning Statement for a New Permanent Prison at Addiewell, planning submission on file with West Lothian Council Museum of the Scottish Shale Oil Industry, 2012, http://www.scottishshale.co.uk/GazVillages/AddiewellVillage.html

Paulsen, K, 2007, Strategy and Sentiment, Qualìtative Sociology 30:1-19

Planning Aid Scotland, 2012, 8. Material Considerations, Information Pamphlet, www.planningaidscotland.org.uk.

Randall SC, 1990, "Studies of the Scottish oil shale industry" Vol.1: A Socio - historical study of Scottish shale mining communities in Midland West Lothian, Final report on US Department of Energy Agreement no.DEAC02- 84ER66199, Research Report TM/90/02, (IOM, Edinburgh)

Redwood II, 1897, A Practical Treatise on Mineral Oils and Their By-Products, London: Spon \& Chamberlain.

Reed, A, 2006, “Documents Unfolding”, in Documents: Artifacts of Modern Knowledge Ed Annelise Riles, (University of Michigan Press, Ann Arbor) pp 158-177

Scottish Wildlife Trust, 2012, http://scottishwildlifetrust.org.uk/reserve/addiewell-bing/ Shore C and Wright, S Eds, 1997, Anthropology of Policy: Critical Perspectives on Governance and Power (Routledge, London)

Simmel G, 1964[1908], “The Stranger” The Sociology of Georg Simmel Ed and transl K Wolff (The Free Press, New York)

Stone D, 2002, Policy Paradox: The Art of Political Decisionmaking, revised edition (Norton \& Co, New York) 
The Scotsman, 2003, “Residents voice fears of new prison”, 31 October, http://www.scotsman.com/news/residents_voice_fears_of_new_prison_1_902683

The Scotsman, 2004a, “Call for answers over prison plan”, 17 January, http://www.scotsman.com/news/call-for-answers-over-prison-plan-1-920003

The Scotsman, 2004b, "Protesters up the stakes in row over jail” 22 January, http://www.scotsman.com/news/protesters-up-the-stakes-in-row-over-jail-1-920472

The Scotsman, 2004c, “Controversial prison plan gets go-ahead”, 2 July, http://www.scotsman.com/news/controversial_prison_plan_gets_go_ahead_1_1021 $\underline{985}$

Topal C, 2009, “ The Construction of General Public Interest: Risk, Legitimacy, and Power in a Public Hearing” Organization Studies 30(02\&03) 277-300

Vaughan, D, 2004, “Theorizing disaster: Analogy, historical ethnography, and the Challenger accident’ Ethnography 5(3) 315-347

Wacquant L, 2001, “Deadly Symbiosis: When Ghetto and Prison Meet and Mesh” Punishment \& Society, 3(1) 95-133

West Lothian Council, 2002 West Lothian Strategic Action Plan 2002-2005, Livingston Widdowfield R, 2000, “The place of emotions in academic Research” Area 32 199-208

Wolsink M, 2006, “Invalid theory impedes our understanding: a critique on the persistence of the language of NIMBY” Transactions of the Institute of British Geographers 31(1) 85-91

Woods M, 2007, “Engaging the global countryside: globalization, hybridity and the reconstitution of rural place” Progress in Human Geography 31(4) 485-507 